\title{
Nature of the Power of the Registrar of Titles: Judicial, Quasi-Judicial or Administrative
}

\author{
Shahrul Natasha Halid \\ JADY ZAIDI HASSIM
}

\begin{abstract}
As a country with Torrens land registration system, the Registrar of Titles plays a key role in managing and maintaining the land registration in Malaysia. The powers and duties conferred upon the Registrar of Titles under the National Land Code 1965 are manifold, ranging from the power to conduct enquiries, the power to enter the Registrar's caveat, the power to issue an arrest, the power to issue title and others. The nature of the power of the Registrar of Titles is often under judicial scrutiny due to the direct effect of the Registrar of Titles' actions towards registration of instruments. The issue which seems to be fuddled is whether such power is considered as quasi-judicial or merely administrative? This paper undertakes to provide an answer to such a question. Content analysis will be used in this paper by evaluating the laws and case precedents in Malaysia and Australia. This paper concludes that due to the differences in the structure of the land administration organisation and also the provisions of the Malaysian National Land Code 1965 compared to those in Australia, there is a tendency for the courts in Malaysia to limit the nature of the power of the Registrar of Titles. Despite the myriad of powers and duties afforded to the Registrar of Titles in Malaysia, in reality, the powers are legally restricted and the position is merely considered as an automaton in the land registration system.
\end{abstract}

Keywords: judicial powers, quasi-judicial powers, land administrators' powers, National Land Code 1965, Registrar of Titles, Torrens land registration system.

\section{INTRODUCTION}

The land registration system in Malaysia was modelled on the Australian Torrens system. The Torrens system is designed to provide simplicity, certainty and security for land dealings. Colonialism and democratization are a crucial factor that leads to the adoption of the Torrens system in Malaysia. Under the Torrens system, the Registrar is considered to be the cornerstone of the land registry system as the person behind the application and implementation of such a scheme.

The term Registrar is defined under section 5 of the National Land Code 1965 as a Registrar of Titles or Deputy Registrar of Titles appointed under section 12 in relation to land held or to be held under Registry title, or under the form of qualified title corresponding to Registry title, or under subsidiary title dependent on a Registry title. The Registrar also referred to the Land Administrator in relation to land held or to be held under the Land Office title, or under the form of qualified title corresponding thereto, or under subsidiary title dependent on a Land Office title.
In Malaysia, the Registrar is considered as a public servant as provided under section 21 of the National Land Code 1965. The definition of public servant can be found in section 21 of the Penal Code (Act 574) where there are nine categories of persons who are classified as 'public servants' and it was provided that under section 21(j) that it includes any officer whose duty includes to take, obtain, retain or dispense with any property, to carry out any survey or assessment, or to levy any rate or tax for any secular common purpose of any village, town or district, or to make, authenticate or keep record as to the rights of the people of any village, town or district.

The National Land Code 1965 provide several provisions detailing the numerous powers and duties allocated to the Registrar of Titles. Such powers include the power to conduct attestation of instruments, power to require the production of documents, power to determine the fitness of instruments for registration, power to correct errors, power to issue title, power to conduct searches, power to conduct inquiries, power to enter the Registrar's caveat and others. Due to 
the countless powers and duties provided under the law to the Registrar of Titles, there has been an ongoing debate as to the nature and scope of the Registrar's powers. The question to be answered is whether the Registrar's functions are 'judicial', 'quasi-judicial', or 'administrative' in nature. It is important to explore such issue because it will affect the registration of titles and ultimately the concept of indefeasibility.

\section{THE DEFINITION OF JUDICIAL AND QUASI-JUDICIAL}

Lopes LJ appropriately tries to define the term 'judicial' in the Royal Aquarium Society case $^{l}$ when he proclaimed that the word has two meanings; it may refer to the discharge of duties which may be exercised by a judge or a court judge, or to administrative duties which do not need to be exercised in court, but for which it is appropriate to have a judicial mind to what is just and reasonable in the matters under consideration.

However, Lord Reid in Ridge $v$ Baldwin ${ }^{2}$ explained how the term 'judicial' has been misunderstood as having any super-added characteristics beyond the characteristic that the power affects rights which makes it judicial and thus subject to natural justice proceedings. In other words, it is appropriate to exercise a 'judicial' power that affects rights, which is rational, and the fact that the power is administrative does not make it any the less 'judicial' for this reason.

The concept of quasi-judicial on the other hand indicates that the act is not completely judicial since the word quasi which is of Latin origins means not exactly. It defines only an obligation cast on the executive body or authority to comply with judicial procedural norms when conducting such actions in exercise of its executive powers. The practice of discretion is said to be important in determining the definition of quasi-judicial because when the law commits an officer to investigate such evidence, the role is quasi-judicial not in a manner which it directs directly, but in a discretionary manner in its judicial nature.

Wade referred to quasi-judicial as a term commonly used to identify those kinds of powers exercised by ministers or departments of government, but subject to a degree of judicial oversight in the way they are exercises. It is said to refer to powers that can only be exercised when certain facts are found to exist, and suggests that these facts must be found in compliance with a code of rules known as 'natural justice'. ${ }^{3}$

An effort was made to describe the terms 'judicial' and 'quasi-judicial' in Cooper $v$ Wilson \& Ors ${ }^{4}$. The Court in this case referred to the findings of the Committee on Ministers' Powers in England which stated that a genuine judicial decision presupposes an actual conflict between two or more parties, and then implies four requirements. The first requirement is that the presentation of their argument (not necessarily orally) by the parties to the dispute. Secondly, that if the conflict between the parties is a matter of fact, the determination of the fact by means of evidence illustrate by the parties to the dispute and always with the help of argument on the facts by or on behalf of the parties. Third, if the conflict between them is a matter of law, the parties shall make legal arguments. Fourth, a decision that disposes of the entire matter by a finding the facts at issue and applying the law of the land to the facts found, providing a judgment on any contested question of law where appropriate.

A quasi-judicial decision justly surmises an ongoing conflict between two or more parties and involves the first and second requirement but does not necessarily involve the third and never the fourth. The fourth requirement is taken by administrative action, whose character is decided by the free choice of the Minister.

Abdul Malik Ishak $\mathrm{J}$ in Hoo Lin Coln $v$ Wong Weng Woh \& Anor ${ }^{5}$ cited the definition of quasi-judicial found in A Textbook of Jurisprudence $^{6}$ which stated that the term also encompasses judicial decisions made by an administrative body - the measure is not what the tribunal does, but the essence of the tribunal.

Quasi-judicial is part of the administrative category in England and is used to include cases where the administrator is bound by the legislation to observe such types and can hold a public hearing, but where the final decision is made by a free agent. Such decision can be set aside if the rules are violated, but it is not sufficient to establish that the administration is biased in favour of a certain policy or that the evidence supports a different outcome.

It was held in the case of Province of Bombay $v$ Khuslal Das Advani ${ }^{7}$ that a quasi-judicial act demands that a judgment be 
provided, not arbitrarily or at the sole discretion of an authority, but in compliance with the facts and circumstances of the case, as determined by an enquiry undertaken by the authority after allowing to the party to be concerned the opportunity to be heard and, if appropriate, to provide the requisite evidence in support of its claims.

While Diplock LJ in $R v$ Deputy Industrial Injuries Commissioner, ex $p$ Moore 8 stated that the requirement that a person exercising quasi-judicial functions must base his or her decision on evidence implies no more than it must be based on material which logically appears to show the presence or non-existence of facts relevant to the issue to be decided or to demonstrate the probability or unlikelihood the occurrence of some future event. It means that he must not spin a coin or consult an astrologer, but he may take into account any material which has a probative value as a matter of purpose, the weight to be attached to it being a matter for the person to whom Parliament has delegated the responsibility of deciding the matter. The High Court's supervisory authority does not entitle it to usurp the duty and to replace it with its own view.

Gopal Sri Ram when commenting on the exercise of 'quasi-judicial' powers by the Industrial Court under the Industrial Relations Act 1967) in Syarikat Kenderaan Melayu Kelantan Bhd $v$ Transport Worker's Union ${ }^{9}$ proclaimed that whether performing a quasi-judicial role or a strictly administrative one, the inferior tribunal or any other decisionmaking body has no power to commit an error of law. But Bhagwati $\mathrm{J}$ in the Indian case of Siemens Engineering \& Manufacturing Co $v$ Union of India ${ }^{10}$ was of the opinion that where, in the exercise of a quasi-judicial role, an authority makes an order, it must document its reasons in favour of the order it makes.

On the other hand, the term 'administrative' which can also mean 'ministerial' is used to refer to a particular type of governmental action or to the wide areas of government operations in which all groups of statutory functions are exercised by the repositories of power but such statement is considered misleading since the term and its usage varies. Loosely, it can also use to refer to conduct performed by a minister ${ }^{11}$ but the correct usage in terms of this research is to denote an act involving the performance of a legal duty and the exercise of little or no discretion for example, the duty to issue a certificate of title on payment of the prescribed fee. Administrative powers are being used in the sense of denoting those powers which are neither legislative nor adjudicatory and usually functions which are not categorized as legislative and where there is no requirement to follow natural justice or fairness, are determined as administrative powers. ${ }^{12}$

In executing an administrative function, several elements are said to be in existence, for example an administrative order is focused on governmental policy and that the administrative authority is not bound by the rules of proof and practice until such a duty is enforced by the applicable legislation. An administrative action will also not become a quasi-judicial action merely because it must be performed after forming an opinion as to the existence of any objective fact.

\section{THE DISTINCTION BETWEEN QUASI-JUDICIAL AND ADMINISTRATIVE FUNCTIONS}

Since an administrative authority such as the Registrar of Titles may come to a decision which is purely administrative or quasi-judicial in nature, it is imperative and necessary to differentiate between these two concepts because unless each of these functions is identified, then the procedural requirements, the scope of judicial review and the remedy available cannot be determined properly. ${ }^{13}$ For example, in administrative decisions, there is no legal duty for the person responsible for making the decision to consider and weigh submissions and claims, or to gather any facts or to address any question. ${ }^{14}$ Sometimes, a quasi-judicial decision can also be regarded as an administrative decision, since at some stage it includes element of which has judicial features. ${ }^{15}$

Traditionally, the presumption is that when an authority is acting judicially it is bound by fixed legal objective standards, whereas an authority which is not under any judicial duty may act subjectively according to its own wishes. Indeed, the distinction between judicial and quasi-judicial is also difficult to pinpoint and the easiest way to differentiate between these two is through the type of proceeding it is said to be involved in. 
Tribunals are said to be more of judicial in nature while inquiries are thought as having quasi-judicial function.

It can be observed that in the earlier cases, the Courts have been trying rigorously to define the powers conferred upon administrative authorities since it was held that the Courts can only control an action of an administrative authority if it was done judicially or quasi-judicially but not if it was an administrative duty since the Courts could not interfere with the authority's exercise of its power.

To distinguish between a quasi-judicial act from and an administrative act, it must be determined whether the statutory authority has the duty to act judicially. The real test is to ascertain when does such duty to act judicially occur? Since this is not always an easy thing to do and there is no 'cut and dried' formula to distinguish between these two, the Courts will in most cases take into consideration whether the statute provides an express provision requiring the administrative authority to act judicially. If such provision exists, then the action of the said authority would be a quasi-judicial function.

However, in reality most statutes do not expressly provide for the duty to act judicially and it is true in the case of the National Land Code 1965. Discretion is implied to the Registrar of Titles in performing certain powers such as entering the Registrar's caveat but there's no apparent mention or a clear indication of a judicial power or function in any of the provisions. For example, although the Registrar of Titles can conduct enquiries under several provisions such as section 261 and 311 of the National Land Code 1965, those powers are severely restricted and subject to future interference by the court through appeals by the aggrieved parties under section 418. There is difficulty in distinguishing between the concepts of administrative and quasi-judicial which in turn has led the courts to depend more on the concept of fairness rather than natural justice, so that an increasing function of the administration may be subjected to the requirement of right of hearing of the person affected. Previously, the rule of natural justice is applied to the exercise of only judicial and quasi-judicial functions but through the landmark decision of Ridge $v$ Baldwin ${ }^{16}$, an administrative decision can also attract the rules of natural justice.

\section{THE POSITION IN MALAYSIA}

The courts in Malaysia are of the opinion that the power of the Registrar is purely administrative in its core when it comes to registering of instruments especially in situations where all the necessary requirements have been adhered to ${ }^{17}$. It is generally accepted that the functions exercised by the registering authority are ministerial but in certain matters it can also be quasi-judicial for he has the authority to determine whether the instrument is fit or unfit for registration and may decide to register, suspend or reject the instrument if the situation arises. The Registrar's powers are quasi-judicial where it involves the exercise of discretion but will become purely ministerial when it comes to affect such necessary entries to bring about the registration of an instrument. ${ }^{18}$

In such situation, the Registrar has no right to determine equitable priorities or to even inquire into conflicting inquiries and that his duty is only confined to seeing that the instrument is in accord with the prescribed form, and that it is signed by the parties involved competent to affect a transaction of the sort disclosed by the instrument. The Registrar is therefore not concerned to inquire into the circumstances or even verify the facts stated in the instruments presented and that his duty is certainly limited to registering the instruments presented which has been signed by parties competent in law to affect the dealing represented by the said instruments.

Horne $\mathrm{J}$ in the earlier case of Wong Yew ${ }^{19}$ is of the view that the proper registering authority must be held to have the power to issue subsequent certificates of title and being a quasi-judicial authority may exercise that power at his discretion. But the duties of a Registrar are certainly varied and not limited to only the registration process but also include entering of caveats and conducting enquiries. Such duties merit some form of discretion in order to be fully effective but the risk of being arbitrary in coming to decisions are worrying. When such doubt arises, matters are certainly being brought to the Court for further more authoritative counsel.

In the case of Island \& Peninsular Development Bhd \& Anor $v$ Legal Advisor, Kedah \& Ors ${ }^{20}$, Syed Agil Barakbah J observed that the wording "may make such 
correction on the document" in section 380 of the National Land Code 1965confer a discretion on the Registrar in discharging his powers to make any correction and that this function which involves a discretion is quasi-judicial. However, when the Registrar is satisfied that the mistake or error exist, and then his duty becomes ministerial. The Registrar may well be acting judicially and magisterially during the exercise of different functions, or even at different phases of exercising any one function. ${ }^{21}$

However, in Mohammad bin Buyong $v$ Pemungut Hasil Tanah Gombak \& Ors ${ }^{22}$, it was held that section 380 of the National Land Code 1965 should not be construed by the court to impose on the Registrar an unqualified power to correct or cancel and to enter the register which would be at the very root of indefeasibility of titles. This approach was subsequently followed by several cases including Low Siew Ley v Low Teck Choon ${ }^{23}$ where Zaleha Yusof JC stated that role under section 380 is merely to determine whether there is any genuine minor mistake or error and he is only empowered to correct that minor mistake and error and not go beyond that.

The position of the Malaysian Courts in this matter seemed to be that they are quite unwilling to give a free rein to the Registrar in exercising his so-called quasi-judicial powers and that function are open to rigid scrutiny. However, the Malaysian courts have agreed that in performing powers under section 319 of the National Land Code 1965 which provides for the entering of Registrar's caveats in any title, discretion is required, and the Registrar is actually acting to some extent in a judicial nature. This contrasts with the Registrar's powers relating to private caveats. According to Abdul Malik Ishak $\mathrm{J}$ in AKB Airconditioning \& Electrical Sdn Bhd $v$ Hew Foo Onn \& Anor ${ }^{24}$ there is a long line of authorities which claimed that the role of the Registrar is solely administrative or ministerial in respect of an application for private caveat. The honorable judge further declared that upon sight of Form 19B which is for the application for a private caveat, the Registrar has no discretion but must enter the private caveat that was applied for.

Lord Diplock of the Privy Council when referring to section 320 of the National Land
Code in Registrar of Titles, Johore $v$ Temenggong Securities Ltd \& Anor ${ }^{25}$ also proclaimed that the registrar's functions in relation to registrar's caveats are not purely ministerial. Such duties are also related to the other kinds of caveats. They necessitate that discretion be exercised which is quasi-judicial in its nature. The registrar can only act upon such information as is available to him when deciding whether or not to exercise the power bestowed on him by the said section. This shall consist of what is entered in the registered itself or file in the registry, along with any additional details that may have been given to it by anyone who requested it to exercise its authority to enter the caveat of a register.

Wong Kim Fatt JC in the case of A.R. Palaniappa Chettiar $v$ Letchumanan Chettiar $\&$ Anor $^{26}$ also stated that in the case of an entry of a Registrar's caveat, the Registrar is said to execute a quasi-judicial role in exercise of discretion. Therefore, in the act of performing duties that are either judicially or quasi-judicially in nature, the Registrar must always act reasonably and not arbitrarily, as well in good faith.

Gunn Chit Tuan SCJ in Pendaftar Hakmilik Negeri Kedah v Overseas Chinese Banking Corp. $L_{t d}{ }^{27}$ also proclaimed that the Registrar's functions under the provisions of section 320 of the National Land Code 1965 are not exclusively ministerial and that he exercises a discretion, albeit not totally unfettered, which is quasi-judicial in nature.

However, in $M B F$ Finance Bhd $v$ Pendaftar Hakmilik Negeri Perak \& Anor ${ }^{28}$ even though Peh Swee Chin J recognized that the Registrar has a quasi-judicial discretion to enter a Registrar's caveat, the honourable judge held that pursuant to section $320(1)(\mathrm{ba})$ of the National Land Code 1965 the Registrar cannot refuse to enter a registrar's caveat on the ground that the debt would not come within the meaning of the word 'interest' in the provision since the said provision undoubtedly creates an express statutory right for any government department in respect of any debt due to it from a land owner to apply for a Registrar's caveat.

Abdul Malik Ishak $\mathrm{J}$, in a more recent case of Agrimal Project Sdn Bhd $v$ Pendaftar Hakmilik, Pejabat Tanah dan Galian, Johor \& $O r s^{29}$ did not seemed to follow this view when he declared that the exercise of discretion by 
the registrar cannot be checked except to see that it has in fact been exercised and that exercise was not made mala fide.

Besides powers pursuant to section 380 and section 320, the Registrar is also empowered to conduct enquiries according to the provisions of Chapter 4 of Part Two of the National Land Code 1965. There are many circumstances where the Registrar can decide to hold an enquiry and to some extent the Registrar is acting in an adjudicatory function because the Registrar is responsible to decide questions of fact as well as of law and determine a variety of claims and disputes not only between an individual and a department but also between two individuals.

However, the Courts in Gurpal Singh $v$ Kananayer \& Anor $^{30}$ held that the Collector's powers in enquiry should be limited and he has no power to investigate any allegation of fraud or misrepresentation since he is not empowered under the National Land Code 1965 to adjudicate on the pleadings which were ordinarily heard in the Courts. Peh Swee Chin FCJ in Tan Chiw Thoo $v$ Tee Kim Kuay ${ }^{31}$ also declared that the power of the Registrar to hold an enquiry does not ipso facto grant him the right to determine any matter or right whatsoever in relation to land or title to land under the National Land Code 1965.

Other than the provisions found under the National Land Code 1965, the Land Administrator who also functions as the Registrar can make an award as to the amount of compensation for land acquisition under section 14 of the Land Acquisition Act 1960. George J in Oriental Rubber and Oil Palms Sdn Bhd $v$ Pemungut Hasil Tanah, Kuantan ${ }^{32}$ when commenting upon the Land Administrator's powers under this Act stated that the Collector in holding his enquiry is clothed with judicial powers and section 14(1) of the Land Acquisition Act 1960 makes it mandatory for him to prepare a written award which shall be final and conclusive evidence of the value of the land in the opinion of the Collector (section 14(2)). The learned judge further pointed out that the implementation of section 16 of the Land Acquisition Act 1960 may be a strictly administrative action but the holding of the enquiry pursuant to section 12 and the making of the award pursuant to section 14 are quasi-judicial functions which could and do affect the individual.

In his judgment, the learned judge cited the case of Ketua Pengarah Kastam v Ho Kwan Seng $^{33}$ and noted that there is an emerging trend to adopt a more liberal approach in deciding if the individual is adversely affected by an administrative action. It is suggested in this case that the rule of natural justice has to be observed to determine whether the action is labelled judicial, quasi-judicial or even administrative.

The Federal Court in Pemungut Hasil Tanah, Daerah Barat Daya, Pulau Pinang v Kam Gin Paik $^{34}$ also held that it is fairly clear from the language of section 12 that the function of the Collector (referring to the land administrator) is not merely administrative, though a fair exercise of discretion is implied. If the Registrar in conducting enquiries can be regarded as having a quasi-judicial power, then the judgment in Syarikat Kenderaan Melayu Kelantan Bhd $v$ Transport Workers' Union ${ }^{35}$ should be observed. It was held that a lower tribunal or decision-making body, whether performing a quasi-judicial role or purely an administrative one has no jurisdiction to commit an error of law.

\section{THE POSITION IN AUSTRALIA}

As in Malaysia, views as to the nature of the Registrar's duties whether they are ministerial or judicial have been made by the Courts and were not always consistent. To some extent all powers (as distinct from duties) are discretionary but cases arise in which it may be difficult to distinguish a power from a duty. ${ }^{36}$

For example, in In re the Registrar-General, ${ }^{37}$ the Registrar-General refused to register the transfer of a certain land to a company because it was not shown to him that the purchase of the land included in the transfer was incidental or conducive to the attainments of the objects of the said company. G.B. Simpson J. in this case held that the Registrar-General duties being purely ministerial therefore, it is not within his power to inquire whether the purchasing of the land was incidental to the attainments of the objects of the company or not. In Re Strahorn ${ }^{38}$ Rich J stated that: 
“... the belief that the Registrar-General was competent to decide as to the validity of his (bona-fide purchaser) title; that is, of course, an erroneous view - where the Registrar-General has presented to him for registration by the grant or certificate of title of the land affected by the transfer his duty to register the same is purely ministerial and not judicial. There being no caveat or injunction against the registration, and nothing appearing on the register to interfere with the same, he had no option but to register".

Griffith C.J. in Crowley v Templeton ${ }^{39}$ also proclaimed that the work of the Registrar is intended to be to a great extent, not mechanical but automatic as the instruments which the Registrar is to be called upon to register are to be such as not to involve difficult questions of law or interpretation of documents, except so far as to record bargains made by the parties which they have a right to make. In Ex parte Bond ${ }^{40}$ the court held the principle that judicial duty is imposed on the Registrar when examining the validity of instruments presented to him for registration and followed the decision of the Privy Council in Registrar of Titles $v$ Paterson ${ }^{41}$ where it was held that there is discretion on the Registrar since the responsibility is upon him in preventing instrument being registered which in law, as in fact, ought not to be placed on the register. In In Re The Transfer of Land Statute, Ex Parte the Mutual Trust and Investment Society Limited, ${ }^{42}$ the same approach was also taken by the Court. The appellant in this case applied for a Rule nisi for a mandamus to compel the Registrar to show cause why he should not give his reasons for refusing to call in the certificate of title to one O'Connell. It was held that since it did not appear that the certificate of title had been issued in error within the meaning of section 132 of the Transfer of Land Statute (Victoria) then the matter is entirely for the discretion of the Registrar. The appeal was subsequently dismissed. Isaacs $\mathrm{J}$ in The Perpetual Executors and Trustees Association of Australia, Ltd. v Hosken ${ }^{43}$ also declared that the Registrar is not simply considered as an automaton because he has an immense and responsible public duty to discharge.

In Australia, the need for classification was prompted by the principle of law that an action will lie against the Registrar for the breach of a statutory duty when it is administrative but not in the instances when it is judicial or quasi-judicial. If the powers are considered as discretionary, the Court will not interfere and direct the Registrar to do something that he refuses to perform. For example, in the case of Lee Mong Kow $v$ Registrar-General of Titles $^{44}$ it was held that where the Registrar comes to a conclusion in the exercise of his discretion and that conclusion even if it is erroneous cannot form the basis for a claim for compensation. It was found that the phrase 'omission, mistake or misfeasance' refers to clerical or similar errors in the land titles office and misfeasance that causes loss and does not extend to errors of judgment honestly made on evidence before the Registrar.

In Ex parte Gallagher, ${ }^{45}$ the Registrar-General had refused to issue a summon to one Henry Phillip to deliver a Crown Grant which had been issued in error for the purpose of the title being subsequently cancelled or corrected. The Court in this case had to determine whether an application for the writ of mandamus should be made to command the Registrar-General to summon the said person. The Court refused to grant a mandamus and the Chief Justice stated in his judgment that the matter is entirely in the discretion of the Registrar-General and the Court would not interfere since the onus is thrown upon the Registrar-General to be judicially satisfied.

Hodges $\mathrm{J}$ in The King $v$ Registrar of Titles, ex parte Briggs, ${ }^{46}$ when addressing the discretionary powers of the Registrar to refuse to register a transfer unless it is shown that there is no possibility of a breach of trust stated that the Court will not compel the Registrar to register such dealing. Powers $\mathrm{J}$ also proclaimed as such in $R v$ Registrar of Titles (Vic); Ex parte Commonwealth ${ }^{47}$ when he stated that the Registrar has also a duty to refuse to register a document if it is clear that it purports to effect a transaction which the registered proprietor is not by law justified in effecting.

In the case of Templeton $v$ Leviathan Pty Ltd ${ }^{48}$ (1921) 30 C. L. R. 34, Higgins J. stated that the Registrar has to discharge not merely ministerial but also judicial duties; and it is his duty to "prevent instruments from being registered which in law, as well as fact, ought not to be placed on the register".

This view was later followed in Gibb $v$ Register of Titles $^{49}$ where it was held that 
the Registrar is not an automaton whose duty it is to register all documents affecting title to land under the (Australian) Transfer of Land Act. What can be deduce from this case is that it is often hard to determine whether a particular administrative power has been done in the exercise of discretion, or merely in the implementation of general policy which, although based on a discretionary power has developed into a practice.

Virtue $\mathrm{J}$ in Wydgee Pastoral Company Pty Ltd $v$ Registrar of Titles ${ }^{50}$ also referred to the judgment in the Templeton case and held that the Registrar of Titles is justified in refusing to register a document if the transfer was to achieve a purpose which on the face of the conditions imposed was made unlawful according to the law. In In re Ford's Application, ${ }^{51}$ Morris $\mathrm{J}$ was of the view that if the proper registering authority has exercised their discretionary power properly then their decision should not be disturbed. But it must be observed that such powers must be exercised within the limit to which an honest man competent to discharge his office ought to confine himself ${ }^{52}$ and such discretionary powers does not give an authority an arbitrary and uncontrolled power. ${ }^{53}$ Compensation can be made for omission, mistake or misfeasance of the Registrar but such provision does not impose an absolute liability upon the Registrar. Instead, liability is only imposed where there is loss suffered through such omission, mistake or misfeasance. As stated before, claims can however be barred if such omission occurred from the exercise of the Registrar's discretion.

The term 'discretion' has been aptly defined in Rooke's Case ${ }^{54}$ where it means that something must be done within the discretion of the authorities and that something is to be done in compliance with the laws of reason and justice, not according to private opinion. In Wilson $v$ Rastall, ${ }^{55}$ it was also held that discretion is to be not arbitrary, ambiguous, and fanciful, but legal and regular and to be exercised within the limits to which an honest person competent to the discharge of his office should be confined. To avoid arbitrariness, checks upon discretion is a natural process. ${ }^{56}$ In Associated Provincial Picture Houses v Wednesbury Corporation ${ }^{57}$, Lord Greene stated the principle that when an executive discretion is entrusted to a local authority by the Parliament, that control can only be disputed in a very restricted class of cases in the courts.

Most of the powers conferred upon the Registrar under the statutes which includes administering oaths, summoning a person to appear before him or the power to require the production of documents are in fact discretionary. Further, it was held in Tinning $v$ Oliver $^{58}$ that such powers should not be used if their exercise would result in the defeat of equitable rights.

In cases where the exercise of the powers does not in any way result in any rights being at risk then the powers will not be challenged. For example, in the case of In Re Armitage, Ex parte Andrews, ${ }^{59}$ the mortgagee argued that an order cannot be made compelling them to produce a certificate of title for the purpose of having a transfer registered on the grounds that there exist a covenant in the mortgage which provided that they shall have the custody of the certificate of title and that the mortgagor is in default. It was held that the provisions of the Transfer of Land Act 1890 (Victoria) requiring the production of the certificate of title override the covenant and that since the transfer is for the benefit of the creditors it should be registered.

Isaacs $\mathrm{J}$ in The Registrar-General (South Australia) $v$ Wright $^{60}$ also took the same view when he proclaimed that the Registrar-General is empowered by the law to perform his statutory duties. In this case, the mortgagee refused to produce the certificate of title for the purpose of having a transfer registered after the Registrar-General had issue a summons under section 220(3) of the South Australia Real Property Act 1886.

As in Malaysia, the Registrar is empowered under all of the Australian legislations to make certain corrections in the register but there are two separate but overlapping provisions relating to the Registrar's powers of correction in Australia. One of the overlapping provisions is the so-called 'slip provision' contained in all of the Australian Torrens legislations except for Queensland and the Northern Territory provides for general correction of errors and omissions in the register. Whether such provisions entailed a quasi-judicial nature of the Registrar's powers has always been up for debate. Lord Wilberforce when commenting on a similar provision found in section 80 of the New 
Zealand Land Transfer Act 1952 in Frazer $v$ Walker $^{61}$ stated that such provision is to be nothing more than a slip section and not of substantive significance.

This rather rigid approach was later on followed by the Australian courts and it was even suggested that the Registrar when executing such duty provided under the slip provision is neither permissible nor appropriate to assume a judicial role in adjudicating issues of law or fact and such role is for the courts. ${ }^{62}$ There is also the view that the Registrar-General can only use this power to correct administrative errors and slips. ${ }^{63}$

Justice Kitto in Pirie $v$ Registrar-General ${ }^{64}$ was, however, of the opinion that the RegistrarGeneral as head of the department authorized to carry the provisions of the Act into execution is under a general duty to keep the register book clear of all notification save those which are authorized by law. The New South Wales Court of Appeal in the case of James $v$ The Registrar-General ${ }^{65}$ departed from the decision of Frazer $v$ Walker $^{66}$ by proclaiming that the New Zealand section does not contain the Australian proviso or the quoted last paragraph of section 12 (d) and therefore the correction of the omission of a duly created easement would normally be within the competence of the Registrar-General. Unfortunately, the decision in James $v$ Registrar-General ${ }^{67}$ was later on considered as too controversial since the courts impliedly stated that the Registrar has certain discretion in exercising his powers of correction.

McPherson $\mathrm{J}$ in Medical Benefits Funds of Australia Ltd $v$ Fisher ${ }^{68}$ took a narrower view when he stated that a provision departing from the system's at so cardinal a point by granting the Registrar-General a discretionary power to detract from indefeasibility of a registered title should be viewed with the utmost strictness. However, there is indeed another provision relating to the Registrar's power of correction which is more extensive in nature and has been described by the Privy Council in Frazer $v$ Walker $^{69}$ as giving the Registrar's significant and extensive powers. Such provision provided that in several instances, the Registrar may require any person to submit the certificate of title or duplicate registered dealing to have it cancelled or corrected.
The circumstances that enabled the Registrar to do so are where; a certificate of title was given in error or contains a misdescription of land, a recording in the register has been made in error, a certificate of title or recording was obtained fraudulently or wrongfully, or a certificate of title or duplicate registered dealing is held fraudulently or wrongfully. ${ }^{70}$

In Queensland and the Northern Territory, the Registrar's powers in correction is rather substantive to the point that the Registrar may even hold an inquiry to satisfy himself whether a register should be corrected or not. Section 19 of the Queensland Land Title Act 1994 also provided that the Registrar may hold an inquiry to decide whether a register should be corrected. From these two provisions, it is apparent that the Registrar may exercise his discretion in this regard and when he is satisfied on inquiry that the register is to be corrected then he is empowered to dispense his power of correction.

Since the Registrar is empowered to do so, it is hereby suggested that the Registrar's power of correction according to the Queensland and the Northern Territory provisions is adjudicative ${ }^{71}$ as there is more substantial power for the Registrar to use the power of correction in circumstances where no prejudice will occur. ${ }^{72}$

\section{CONCLUSION}

Despite the number of judgments reflecting on the nature of the Registrar's powers, what can be said is that the views are certainly mixed. Malaysian judges tend to favour that the judicial and quasi-judicial nature of the Registrar's powers are only confined to the very task of entering of the Registrar's caveats, but Australian courts demonstrate a readiness to recognize that the Registrar possess potentially wide judicial powers pertaining to even the registration of instruments.

Although Malaysia adopted the Torrens system of land registration from Australia, the provisions of the National Land Code 1965 cannot be said to be in pari materia with the various Australasian statutes regarding land transfer. Even though some similarities are evident, Australian statutes appeared to give extensive power to the Registrar to practice their discretionary power up to the extent that it can be considered as 'judicial' in nature. 
The differences of statute relating to the Registrar's powers in both countries should be considered but it's apparent that the courts in Malaysia showed such strong stance of judicial conservatism and the reluctance to allow the Registrar more freedom in performing their task in a quasi-judicial nature. Official discretion is historically considered as a legitimate and central part of a modern government $^{73}$ but there is a clear distinction if the use of it showed a drastic departure from pre-existing policy or just merely a change policy. ${ }^{74}$

The requirement to act judicially or even quasi-judicially is nothing more than a requirement to act fairly since some scholars suggest that the procedures which are deemed inherent in the exercise of a quasi-judicial power are merely those which promote a just and equitable judgment. Maybe it is time for the Malaysian Courts or even the government to further expand the Registrar of Titles powers so that they can play a more active role in the land registration system rather than being relegated as a simple 'automaton' whose job is to simply supervise and maintain the register.

\section{NOTES}

[1892] 1 QB 431.

[1964] AC 40.

H.W.R. Wade, Quasi-Judicial and its Background, The Cambridge Law Journal, 10, 1949, p 216.

[1937] 2 KB 309.

[2006] 3 CLJ 939.

6 G. W. Paton \& David P. Derham, A Textbook of Jurisprudence, $4^{\text {th }}$ ed, Oxford Clarendon Press, 1972.

AIR 1950 SC 222

[1965] 1 QB 456.

[1995] 2 MLJ 317.

AIR 1976 SC 1785.

11 S. D. Hotop, Principles of Australian Administrative Law, Sixth Edition. Sydney: The Law Book Company Limited, 1985.

12 MP Jain, Administrative Law of Malaysia and Singapore, Third Edition. Malayan Law Journal, 1997.

13 S P Sathe, Administrative Law, Sixth Edition, Butterworths, New Delhi, 1998.

14 D C M Yardley, Principles of Administrative Law, Butterworths, London, 1981.

15 Report of the Donoughmore-Scott Committee on Ministers' Powers, 1932

16 [1964] A. C. 40.

17 Maidin, A. J., S. A. Kader, S. Z., M. Ali, B. B., Mohamad, N. A., Sufian, A., Rosli, R. A. \& Md. Nor, F. Principles of Malaysian Land Law, Malayan Law Journal, Kuala Lumpur, 2008. Journal, Singapore, 1963

19 [1941] 1 MLJ 33

20 [1973] 2 MLJ 71

${ }^{21}$ Whalan, D. J. The Torrens System in Australia. Sydney: The Law Book Company Ltd., 1982.

[1982] 2 MLJ 53

[2009] 1 LNS 425.

[2002] 5 MLJ 391.

[1976] 2 MLJ 44.

[1982] 1 MLJ 232.

[1990] 2 CLJ 1105.

[1990] 3MLJ 437.

[1998] 5 MLJ 673.

[1976] 2 MLJ 34

[1997] 2 MLJ 221.

[1983] 1 MLJ 315.

[1977] 2 MLJ 152.

[1983] 2 MLJ 392.

[1995] 2 MLJ 317.

36 R. A. Woodman \& P. J. Grimes. Baalman's The Torrens System in New South Wales, The Law Book Company Ltd, 1974.

37 (1900) 21 L.R (N.S.W.) 225.

$38 \quad$ (1912) 29 W.N. (N.S.W.) 7.

$39 \quad$ (1914) 17 CLR 457.

(1880) 6 V.L.R (L) 463.

(1875) 2 App Cas. 110.

(1885) 11 V.L.R. 166.

(1912) 14 C.L.R. 286.

(1923) 32 B.C.R. 148.

(1908) 8 S.R. (N.S.W.) 230.

[1913] V.L.R. 549.

(1915) 20 C.L.R. 379.

(1921) 30 CLR 34.

(1940) 63 CLR 503.

[1963] W.A.R. 176.

[1953] Tas. S.R. 21.

Sharp v Wakefield, (1891) A.C 173.

Steinhouse v Coleman, (1944) 69 C.L.R. 457

(1598) 5 Co. Rep. 996.

(1792) 4 T.R. 753.

56 Sian Elias, 'Looking Back, Looking Forward: Reflections on 50 Years in the Law' (2017) Auckland University Law Review, Vol 23, p 14.

(1948) 1 K. B. 233.

(1927) 22 Tas. L.R. 50.

(1891) 17 V.L.R. 77.

(1917) 23 C.L.R. 214.

[1967] 1 AC 569.

62 Natalie Skead \& Penny Caruthers, 'The Registrar's powers of correction: Alive and well, though perhaps unwelcome? Part I' (2010) (18) Australian Property Law Journal, p 32.

63 Peter Butt, Introduction to Land Law, The Law Book Company, 1980.

$64 \quad$ (1962) 109 CLR 619.

65 (1967) 69 SR (NSW) 361.

[1967] 1 AC 569.

(1967) 87 WN (pt 2) NSW 239

(1984) 1 QLR 606.

[1967] 1 AC 569.

70 Section 136(1) of the Real Property Act 1900 (NSW). 
71 Natalie Skead \& Penny Caruthers, 'The Registrar's powers of correction: Alive and well, though perhaps unwelcome? Part II' (2010) (18) Australian Property Law Journal, p 149.

72 Michael Weir, 'Registrar's Power of Correction Queensland Reforms' (1998) (6) Australian Property Law Journal, p 101.

73 D. J. Galligan, A Legal Study of Official Discretion, Oxford Clarendon Press, 1986.

74 Yoav Dotan, 'Why Administrators Should be Bound by Their Policies' (1997) 17 Oxford Journal of Legal Studies, $\mathrm{p} 23$.

\section{REFERENCES}

Behrends, F.R. \& Elliott, S.D. 1931. Responsibilities and liabilities of the transfer agent and registrar. Southern California Law Review 4(3): 203-219.

Butt, P. 1980. Introduction to Land Law. Sydney: The Law Book Company.

Das S. K. 1963. The Torrens System in Malaya. Singapore: Malayan Law Journal.

Dotan, Y. 1997. Why administrators should be bound by their policies. Oxford Journal of Legal Studies 17: $23-42$.

Elias, S. 2017. Looking back, looking forward: Reflections on 50 years in the law. Auckland University Law Review 23: 14-28.

Galligan, D. J. 1986. A Legal Study of Official Discretion. London: Oxford Clarendon Press.

Hotop, S. D. 1985. Principles of Australian Administrative Law. $6^{\text {th }}$ edition. Sydney: The Law Book Company Limited.

Keong, L. C. 1994. The Registrar's Caveat: A boon for the inland revenue department in Malaysia. Asia Pacific Law Review 3(1): 74-83.

Maidin, A. J., S. A. Kader, S. Z., M. Ali, B. B., Mohamad, N. A., Sufian, A., Rosli, R. A. \& Md. Nor, F. 2008. Principles of Malaysian Land Law. Kuala Lumpur: Malayan Law Journal.

M.P. Jain. 1997. Administrative Law of Malaysia and Singapore. $3^{\text {rd }}$ edition. Malayan Law Journal.
Paton, G. W. \& Derham, D. P. 1972. A Textbook of Jurisprudence. $4^{\text {th }}$ edition. London: Oxford Clarendon Press.

Sathe, S. P. 1998. Administrative Law. $6^{\text {th }}$ edition. New Delhi: Butterworths.

Scott, S. 1999. Indefeasibility of Title and the Registrar's Unwelcome S81 Powers. Canterbury Law Review 7(2): 246-264.

Skead, N. \& Caruthers, P. 2010. The Registrar's powers of correction: 'Alive and well, though perhaps unwelcome?' Part I: The Slip Provision. Australian Property Law Journal 18: 32-47.

Skead, N. \& Caruthers, P. 2010. The Registrar's powers of correction: 'Alive and well, though perhaps unwelcome?' Part II: The Substantive Provision. Australian Property Law Journal 18: 132-149.

Whalan, D. J. 1982. The Torrens System in Australia. Sydney: The Law Book Company Ltd.

Wade, H. W. R. 1949. Quasi-Judicial and its Background. The Cambridge Law Journal 10: 216-240.

Weir, M. 1998. Registrar's Power of Correction Queensland Reforms. Australian Property Law Journal 6: 2-10.

Woodman, R. A. \& Grimes, P. J. 1974. Baalman's The Torrens System in New South Wales. Australia: The Law Book Company Ltd.

Yardley, D. C. M. 1981. Principles of Administrative Law. London: Butterworths.

Shahrul Natasha binti Halid

Fakulti Undang-Undang

Universiti Kebangsaan Malaysia

Email: tcsg888@yahoo.com

Jady Zaidi Hassim

Fakulti Undang-Undang

Universiti Kebangsaan Malaysia

Email: jady@ukm.edu.my 